\title{
CLINICAL AND EPIDEMIOLOGICAL CHARACTERISTICS OF FERTILE AGED WOMEN WITH UTERINE LEIOMYOMA, RESIDENTS OF INDUSTRIAL REGION OF UKRAINE
}

\section{INTRODUCTION}

Healthcare issues are in priority because people's health is the greatest social and individual value, as the health of the population largely influences on the processes and results of the economic, social and cultural development. Therefore they are issues of national security and an important criterion for social development and well-being of the country $[1-3,10]$.

An important parameter characterizing reproductive health of woman is gynecological diseases, their frequency is increasing every year [1, $2,10]$. Among gynecological morbidity in fertile aged women more often appears hyperplasic processes among which the greatest impact on reproductive health has uterine leiomyoma [4-6].

\section{ANALYSIS OF LITERARY DATA}

\section{AND AIM OF THE STUDY}

Leiomyoma is one of the most frequent uterine pathologies. Uterine leiomyoma clinically manifested in $20-30 \%$ of women, in $80 \%$ cases fibroids are removed with following histological examination. Appearances of symptoms of the disease usually increase with age. In the USA, fibroids are the main cause for hysterectomy in women 40 years old and above, the total number ranged in about 30\% of all cases, in Caucasians more than $50 \%$ cases. In women of black race adjusted relative risk of developing uterine fibroids compared to the 3.25 rate of white women in a large prospective cohort $[4,5,7]$.

It is known about close relationship of steroid metabolism with autonomic nervous system, which provides mechanisms for homeostasis in the body. Violations in steroid metabolism or autonomic homeostasis can lead to development of pathological processes $[8,9]$.

The aim of study is to provide clinical and epidemiological characteristics of fertile aged women with uterine leiomyoma residents of the industrial region of Ukraine.

\section{MATERIALS AND METHODS}

Clinical and epidemiological studies have been provided in a population of fertile aged women to determine the frequency and structure of violations of reproductive health. Research has been done in the Dniprovskyi district of Kyiv, which was chosen as the one that corresponds to the typical industrial region of Ukraine. We examined 1000 fertile aged women, residents of Dniprovskyi district of Kyiv. For the clinical and epidemiological program a special questionnaire "Study of reproductive health of fertile aged women" was created - brochure contains 3 sections: "Basic questionnaire", "Your family" and "Medical interview". Questionnaires were distributed among fertile aged women. After completing 2 sections of questionnaire: "Basic questionnaire" and "Your family" women were invited to the doctor, where part "Medical interview" was filled together with medical examination and special examinations.

Clinical and epidemiological studies were population-based, cohort prospective studies. Determination of the population of fertile aged women and individual work with each woman held according to existing methods of clinical epidemiology and the principles of bioethics.

All information was inputted in paper media, were introduced later in the computer memory, thereby a computer database of surveyed women fertile aged women was created and provided further analysis of research results.

Statistical analysis was performed using applications MS Excel 2003, and SigmaPlot ${ }^{\circledR}$ 13.0. The reliability of data for independent samples calculated using the Student t-test. Confidence intervals were calculated by a Wald normal distribution.

\section{STUDY RESULTS AND DISCUSSION}

The results of clinical and epidemiological studies have shown that the incidence of uterine leiomyoma in 1000 fertile aged women in the study area is 53.0 (5.3\%).

According to official statistics the frequency of uterine leiomyoma in fertile aged women (1000 women) in the Dniprovskyi district of Kyiv on average for 5 years was 5.1, and differs from the overall frequency in the Kyiv, which is 4.4. The lowest rate in the Dniprovskyi district was in 2010 and amounted to 4.6 against the highest in $2013-$ 5.6. Also, the trend of increasing frequency of uterine leiomyoma observed in the whole city, where these rates in 2009 were minimal and increased in 2011 (respectively 3.9 and 4.6).

Annually, the clinical supervision on uterine leiomyoma in medical institutions in the Dniprovskyi district in average for 5 years was done for 4802 women, and 22092 women in all Kyiv. Thus, every year clinical supervision on uterine leiomyoma adds in average 779 women, and overall in Kyiv 5287 women; withdrawn from clinical supervision in the Dniprovskyi district 854 and 5248 women in Kiev.

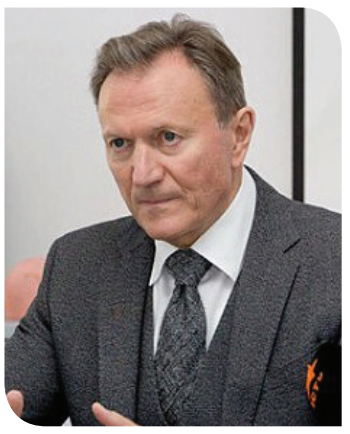

V.M. ZAPOROZHAN

MD, professor, Vice President of the National Academy of Medical Sciences of Ukraine, Rector of Odesa National Medical University, Head of the Obstetrics and Gynaecology Department № 1

VL.V. PODOLSKY

candidate of med. sciences, head of the research group, senior researcher, head of the Department of Health Problems of Fertile Aged Women,

State Institution "Institute of

Pediatrics, Obstetrics and

Gynecology of the National Academy of Medical Science of Ukraine"

Contacts:

Podolskyi Volodymy IPOG of the NAMS of Ukraine, Department of Health Problems of Fertile Aged Women

8 Maiborody str., laboratory building 04050, Kyiv, Ukraine

cell: +38 (067) 4475799 tel. +38 (044) 4844064 e-mail:podolskyivv@gmail.com 
Thus, due to the recovery on leiomyoma in the Dniprovskyi district $15.3 \%$ of women, and overall in Kyiv $18.7 \%$ of women were removed from clinical supervision. The difference is almost $3 \%$ is reserve for more effective treatment of uterine leiomyoma in the Dniprovskyi district.

It should be noted that in average over five years rates of clinical supervision withdrawal due to recovery of symptomatic uterine leiomyoma is $25.32 \%$, and in Kyiv is $43.76 \%$. The data of effective treatment and removal of clinical supervision women with uterine leiomyoma shows that treatment for women with symptomatic uterine leiomyoma is done much better.

Fertile aged women that had uterine leiomyoma were in the age group of 30-40 years at most (Tab. 1). Rate of uterine fibroids in the age of 26-30 years was $22.6 \%$, in women aged $31-35$ uterine leiomyoma was diagnosed in $28.3 \%$ and in the age $36-40$ years in $18.9 \%$ of women.

TABLE 1. RATES OF UTERINE FIBROIDS IN FERTILE AGED WOMEN BY AGE

\begin{tabular}{|c|c|c|}
\hline Age, years & The number of fertile aged women with uterine leiomyoma \\
\hline $15-19$ & $\mathrm{n}^{*}$ & $\%$ (range) \\
\hline $20-25$ & - & - \\
\hline $26-30$ & 5 & $9.4(1.6-17.3)$ \\
\hline $31-35$ & 12 & $22.6(11.4-33.9)$ \\
\hline $36-40$ & 15 & $28.3(16.2-40,4)$ \\
\hline $41-45$ & 10 & $18.9(8.3-29.4)$ \\
\hline $46-49$ & 7 & $13.2(4.1-22.3)$ \\
\hline$* 0=0.00192$ & 4 & $7.6(0.4-14.7)$ \\
\hline
\end{tabular}

Most women with uterine leiomyoma had well-being families $-62.3 \%$ (Tab. 2), but $26.4 \%$ of women had incomplete family.

\section{TABLE 2. RATES OF UTERINE FIBROIDS IN FERTILE AGED WOMEN BY MARITAL STATUS}

\begin{tabular}{|c|c|c|}
\hline Marital status & \multicolumn{2}{|c|}{ The number of fertile aged women with uterine leiomyoma } \\
\hline \begin{tabular}{c} 
Well-being family \\
\hline $\begin{array}{c}\text { Not well-being } \\
\text { families }\end{array}$
\end{tabular} & 33 & $\%$ (range) \\
\hline $\begin{array}{c}\text { Incomplete family } \\
\text { amily members who } \\
\text { were convicted }\end{array}$ & 5 & $9.3(1.6-17.3)$ \\
\hline${ }^{*} \mathrm{p}=0.0406$ & 14 & $26.4(14.5-38.3)$ \\
\hline
\end{tabular}

More than half of women with uterine leiomyoma had higher education $-52.8 \%$ and by social status were employees $49.0 \%$ (Tab. 3, 4).

In women with uterine leiomyoma were observed violations of menstrual function (Tab. 5) that in $54.7 \%$ cases manifested as irregular menses, pelvic pain (43.4\%), significant blood loss (52.8\%) and prolonged menstrual cycle (45.3\%).

The development of uterine leiomyoma in fertile aged women took place on a background of pelvic inflammatory diseases (Tab. 6), which manifested in $64.2 \%$ of women and in $22.6 \%$ of women with cervical erosion.
TABLE 3. RATES OF UTERINE FIBROIDS IN FERTILE AGED WOMEN BY LEVEL OF EDUCATION

\begin{tabular}{|c|c|c|}
\hline \multirow{2}{*}{ Level of education } & The number of fertile aged women with uterine leiomyoma \\
\hline High & $\mathrm{n}^{*}$ & $\%$ (range) \\
\hline Student & 28 & $52.8(39.4-66.3)$ \\
\hline Vocational & 5 & $9.4(1.6-17.3)$ \\
\hline Secondary & 12 & $22.6(11.4-33.9)$ \\
\hline Incomplete secondary & 8 & $15.1(5.5-24.7)$ \\
\hline${ }^{*} p=0.00192$ & - & - \\
\hline
\end{tabular}

TABLE 4. RATES OF UTERINE FIBROIDS IN FERTILE AGED WOMEN BY SOCIAL STATUS

\begin{tabular}{|c|c|c|}
\hline Social status & The number of fertile aged women with uterine leiomyoma \\
\hline Pupils and students & $\mathrm{n}^{*}$ & $\%$ (range) \\
\hline Employees & - & - \\
\hline Workers & 26 & $49.0(35.6-62.5)$ \\
\hline Housewives & 11 & $20.8(3.8-31.7)$ \\
\hline Unemployed & 10 & $18.9(8.3-29.4)$ \\
\hline${ }^{*} p=0.001$ & 6 & $11.3(2.8-19.9)$ \\
\hline
\end{tabular}

\section{TABLE 5. MENSTRUAL FUNCTION OF FERTILE AGED WOMEN WITH} UTERINE LEIOMYOMA

\begin{tabular}{|c|c|c|}
\hline \multirow[t]{2}{*}{ Menstrual function characteristics } & \multicolumn{2}{|c|}{$\begin{array}{l}\text { The number of fertile aged women } \\
\text { with uterine leiomyoma }\end{array}$} \\
\hline & $\mathrm{n}^{*}$ & $\%$ (range) \\
\hline $\begin{array}{c}\text { Age of onset of menstruation: } \\
\text { before } 15 \text { years } \\
\text { after } 15 \text { years }\end{array}$ & $\begin{array}{l}31 \\
22\end{array}$ & $\begin{array}{l}58.5(45.2-71.8) \\
41.5(28.2-54.8)\end{array}$ \\
\hline $\begin{array}{l}\text { Duration of menstrual cycle, days: } \\
\qquad \begin{array}{l}21-25 \\
26-28 \\
29-35\end{array}\end{array}$ & $\begin{array}{l}12 \\
17 \\
24\end{array}$ & $\begin{array}{l}22.6(11.4-33.9) \\
32.1(19.5-44.6) \\
45.3(31.9-59.7)\end{array}$ \\
\hline $\begin{array}{l}\text { The amount of blood loss during menstruation: } \\
\text { insufficient } \\
\text { moderate } \\
\text { significant }\end{array}$ & $\begin{array}{l}15 \\
10 \\
28\end{array}$ & $\begin{array}{c}28.3(16.2-40.4) \\
18.9(8.3-29.4) \\
52.8(39.4-66.3)\end{array}$ \\
\hline $\begin{array}{l}\text { Pain during menstruation: } \\
\text { no } \\
\text { minor } \\
\text { strong }\end{array}$ & $\begin{array}{l}12 \\
18 \\
23\end{array}$ & $\begin{array}{l}22.6(11.4-33.9) \\
33.9(21.2-46.7) \\
43.4(30.1-56.7)\end{array}$ \\
\hline $\begin{array}{l}\text { Cycling menstrual function: } \\
\text { regular } \\
\text { irregular }\end{array}$ & $\begin{array}{l}24 \\
29\end{array}$ & $\begin{array}{l}45.3(31.9-59.7) \\
54.7(41.3-68.1)\end{array}$ \\
\hline
\end{tabular}

TABLE 6. GYNECOLOGICAL DISEASES IN WOMEN OF FERTILE AGE WITH UTERINE LEIOMYOMA

\begin{tabular}{|c|c|c|}
\hline Type of gynecological diseases & $\begin{array}{c}\text { The number of fertile aged women } \\
\text { with uterine leiomyoma }\end{array}$ \\
\hline Pelvic inflammatory diseases & $\mathrm{n}^{*}$ & $\%($ range) \\
\hline Cervical erosion & 34 & $64.2(51.2-77.1)$ \\
\hline Endometriosis & 12 & $22.6(11.4-33.9)$ \\
\hline $\begin{array}{c}\text { Polycystic ovary syndrome } \\
*\end{array}=0.031$ & 5 & $9.4(1.6-17.3)$ \\
\hline
\end{tabular}


Many women with uterine leiomyoma (71.7\%) underwent artificial abortion, and had a history of spontaneous abortions (22.6\%) and benign ovarian cysts (16.9\%). A significant number of pelvic inflammatory diseases, artificial abortion certainly led to violations of the balance of sex hormones, which is causing the growth of benign ovarian cysts and uterine leiomyoma (Tab. 7). Some women underwent surgical treatment of uterine leiomyoma (7.5\%), but had a recurrence of tumor growth.

\begin{tabular}{|l|c|c|}
\hline \multicolumn{3}{|l|}{ TABLE 7. RATES OF UTERINE FIBROIDS IN FERTILE AGED WOMEN } \\
THAT HAD GYNECOLOGICAL SURGERY \\
\hline Type of surgery & The number of fertile aged women with uterine leiomyoma \\
\hline Abortion artificial & $\mathrm{n}^{*}$ & $\%$ (range) \\
\hline Abortion spontaneous & 38 & $71.7(59.6-83.2)$ \\
\hline Ovarian apoplexy & 12 & $22.6(11.4-33.9)$ \\
\hline Ectopic pregnancy & 1 & $1.9(1.8-5.5)$ \\
\hline Benign ovarian cysts & 5 & $9.4(1.6-17.3)$ \\
\hline Myomectomy & 9 & $16.9(6.9-27.1)$ \\
\hline$* 0=0.0467$ & 4 & $7.5(0.4-14.7)$ \\
\hline
\end{tabular}

Examined women had different uterine leiomyoma disease duration (Tab. 8).

\section{TABLE 8. DURATION OF UTERINE LEIOMYOMA IN EXAMINED FERTILE AGED WOMEN}

\begin{tabular}{|c|c|c|}
\hline Disease duration, years & $\begin{array}{c}\text { The number of fertile aged women with uterine } \\
\text { leiomyoma }\end{array}$ \\
\hline$>1$ & $n^{*}$ & $\%$ (range) \\
\hline to 2 & 19 & $35.8(22.9-48.8)$ \\
\hline 3 & 27 & $50.9(37.5-64.4)$ \\
\hline 5 & 7 & $13.2(4.1-22.3)$ \\
\hline$>5$ & - & - \\
\hline${ }^{*} p=0.0130$ & - & - \\
\hline
\end{tabular}

Disease duration of more than one year had $35.8 \%$ of fertile aged women two years $-52.9 \%$ and three years $-13.2 \%$.

Leiomyoma's localization (Tab. 9) more frequent was intramural $39.6 \%$ and subserous $16.9 \%$. In 16 women (30.2\%) the localization was not specified.

\section{TABLE 9. RATES OF UTERINE FIBROIDS IN FERTILE AGED WOMEN BY LOCALIZATION}

\begin{tabular}{|c|c|c|}
\hline $\begin{array}{c}\text { Localization of uterine } \\
\text { leiomyoma }\end{array}$ & $\begin{array}{c}\text { The number of fertile aged women } \\
\text { with uterine leiomyoma }\end{array}$ \\
\hline Submucosal & $\mathrm{n}^{*}$ & $\%($ range) \\
\hline Intramural & 7 & $13.2(4.1-22.3)$ \\
\hline Subserous & 21 & $39.6(26.5-52.8)$ \\
\hline Unspecified & 9 & $16.9(6.9-27.1)$ \\
\hline
\end{tabular}

${ }^{*} p=0.00313$

For the location of benign tumors (Tab. 10) frequently observed in the lower segment of the uterus (32.1\%), in the
TABLE 10. RATES OF UTERINE FIBROIDS IN FERTILE AGED WOMEN BY LOCATION

\begin{tabular}{|c|c|c|}
\hline $\begin{array}{c}\text { Location uterine } \\
\text { leiomyoma }\end{array}$ & $\begin{array}{c}\text { The number of fertile aged women } \\
\text { with uterine leiomyoma }\end{array}$ \\
\hline In the uterus & $\mathrm{n}^{*}$ & $\%$ (range) \\
\hline In the lower segment & 13 & $24.5(12.9-36.1)$ \\
\hline In the left or right uterine wall & 17 & $32.1(19.5-44.6)$ \\
\hline On the front wall of the uterus & 10 & $18.9(8.3-29.4)$ \\
\hline On the back wall of the uterus & 6 & $11.3(2.8-19.9)$ \\
\hline${ }^{*} \mathrm{p}=0.004$ & 7 & $13.2(4.1-22.3)$ \\
\hline
\end{tabular}

uterus (24.5\%) and on the left or right wall of the uterus (18.9\%). Almost half of women (41.9\%) had not a large leiomyoma (Tab. 11), uterus size corresponded to 12 weeks of pregnancy, others had size from 13 to 16 weeks (49.1\%).

\section{TABLE 11. RATES OF UTERINE FIBROIDS IN FERTILE AGED WOMEN BY SIZE}

\begin{tabular}{|c|c|c|}
$\begin{array}{c}\text { The size of uterine leiomyoma } \\
\text { (according to the size of the } \\
\text { uterus in weeks of pregnancy) }\end{array}$ & $\begin{array}{c}\text { The number of fertile aged women } \\
\text { with uterine leiomyoma }\end{array}$ \\
\hline Below 12 weeks & $n$ & $\%$ (range) \\
\hline 13-16 weeks & 26 & $49.1(35.6-62.5)$ \\
\hline $17-24$ week & 26 & $49.1(35.6-62.5)$ \\
\hline More than 24 weeks & 1 & $1.9(1.8-5.5)$ \\
\hline
\end{tabular}

By the number of nodes in the uterus (Tab. 12) one node had $64.0 \%$ women, two to three nodes - had $26.4 \%$ and more than three nodes had $13.2 \%$ women.

\section{TABLE 12. RATES OF UTERINE FIBROIDS IN FERTILE AGED WOMEN BY QUANTITY OF NODES}

\begin{tabular}{|c|c|c|}
\hline Quantity of nodes & \multicolumn{2}{|c|}{$\begin{array}{c}\text { The number of fertile aged women } \\
\text { with uterine leiomyoma }\end{array}$} \\
\hline One & $n$ & $\%$ (range) \\
\hline Two or three & 32 & $60.4(47.2-73.5)$ \\
\hline More than three & 14 & $26.4(14.5-38.3)$ \\
\hline
\end{tabular}

Regarding uterine leiomyoma women underwent a sufficient number of diagnostic methods (Tab. 13). All women had pelvic ultrasound. Half of the women (50.9\%) were provided colposcopic examination of the cervix, only $37.8 \%$ of women were provided histological study of the endometrium, endometrial cells for examination in $20.8 \%$ cases were obtained through dilation and curettage, in $3.8 \%$ via hysteroscopy, while $13.2 \%$ using pipelle biopsy. Vaginal swabs were provided in $13.2 \%$ of women, and hormonal testing in $15.1 \%$.

Doppler ultrasound of vessels of internal genital organs of women with uterine leiomyoma provided only in $9.4 \%$ of patients. After the diagnostic manipulations non-surgical and non-hormonal treatment had $39.6 \%$ of women, $22.6 \%$ of women agreed to have a hormonal treatment. Surgical treatment of leiomyoma had $7.5 \%$ of women. 
TABLE 13. METHODS OF DIAGNOSIS AND TREATMENT OF UTERINE FIBROIDS IN FERTILE AGED WOMEN

\begin{tabular}{|c|c|c|}
\hline \multirow{2}{*}{ Methods of diagnosis and treatment } & \multicolumn{2}{|c|}{$\begin{array}{l}\text { The number of fertile aged women } \\
\text { with uterine leiomyoma }\end{array}$} \\
\hline & $\mathrm{n}^{*}$ & $\%$ (range) \\
\hline Dilation and curettage & 11 & $20.8(9.8-31.7)$ \\
\hline Endometrium pipelle biopsy & 7 & $13.2(4.1-22.3)$ \\
\hline Ultrasound & 53 & 100.0 \\
\hline Colposcopy & 27 & $50.9(37.5-64.4)$ \\
\hline Hysteroscopy & 2 & $3.8(1.4-8.9)$ \\
\hline Doppler ultrasound & 5 & $9.4(1.6-17.3)$ \\
\hline Hormonal examination & 8 & $15.1(5.6-24.7)$ \\
\hline $\begin{array}{l}\text { Determination of urogenital } \\
\text { microbiocenosis }\end{array}$ & 7 & $13.2(4.1-22.3)$ \\
\hline $\begin{array}{c}\text { Conservative treatment: } \\
\text { non-hormonal therapy } \\
\text { hormonal therapy }\end{array}$ & $\begin{array}{l}21 \\
12\end{array}$ & $\begin{array}{l}39.6(26.5-52.8) \\
22.6(11.4-33.9)\end{array}$ \\
\hline $\begin{array}{c}\text { Surgery: } \\
\text { laparoscopic } \\
\text { laparotomic myomectomy } \\
\text { hysterectomy without cervix } \\
\text { full hysterectomy } \\
\text { vascular embolization }\end{array}$ & $\begin{array}{l}- \\
4 \\
- \\
- \\
-\end{array}$ & $\begin{array}{c}- \\
7.5(0.4-14.7) \\
- \\
- \\
-\end{array}$ \\
\hline
\end{tabular}

Taking to account that uterine leiomyoma may lead to infertility we paid special attention to characteristics of reproductive function in women with this benign tumor (Tab. 14).

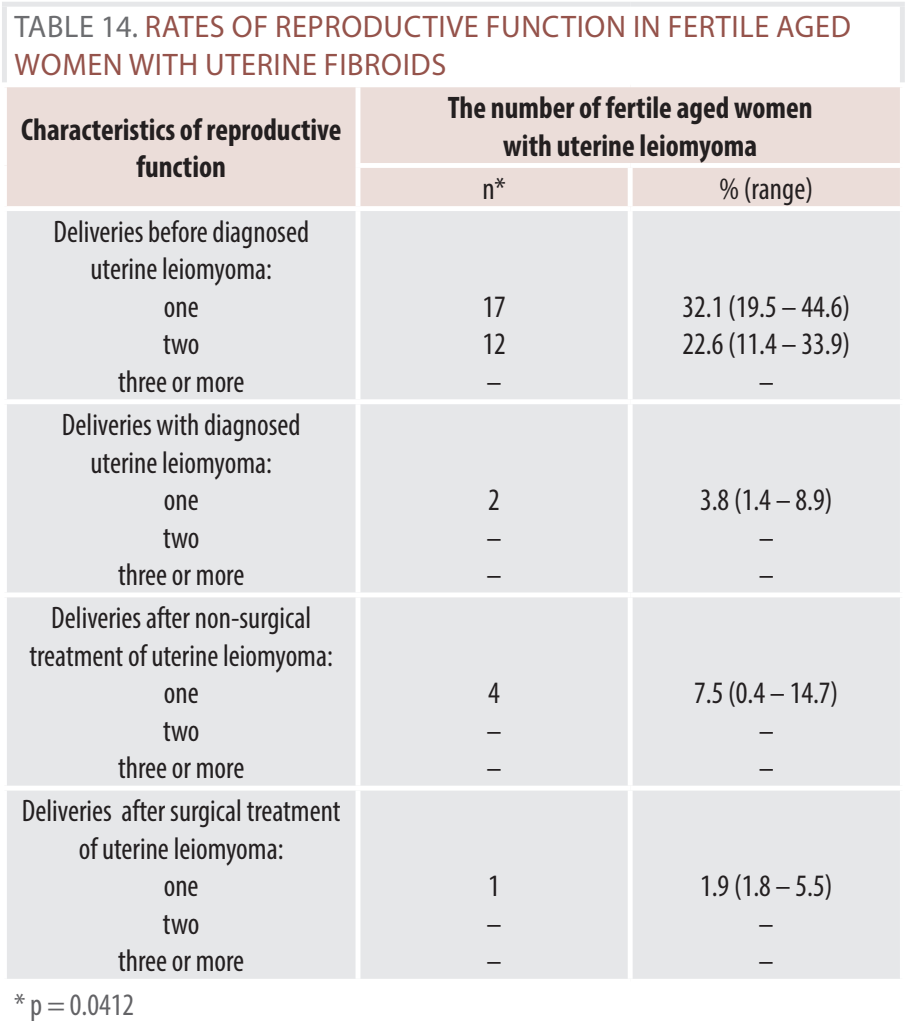

One delivery before diagnosed uterine leiomyoma had $32.1 \%$ of women, and two deliveries had $22.6 \%$. Number of deliveries with diagnosed uterine leiomyoma in surveyed women was insignificant (one delivery had only $3.8 \%$ women). Number of deliveries in women after treatment of uterine leiomyoma with non-surgical methods in this group of women has increased almost twice and amounted $7.5 \%$, and after surgical treatment (conservative myomectomy) 1.9\%.

Women with uterine leiomyoma had concomitant nongynecological diseases (Tab. 15), the most frequent was somatoform dysfunction of the autonomic nervous system $(66.0 \%)$, diseases of the gastrointestinal tract such as cholecystitis (26.4\%) and gastritis (22.6\%). Frequently manifested upper respiratory tract diseases - chronic tonsillitis (18.9\%).

\section{TABLE 15. NON-GYNECOLOGICAL DISEASES IN FERTILE AGED WOMEN WITH UTERINE FIBROIDS}

\begin{tabular}{|c|c|c|}
\hline Non-gynecological diseases & \multicolumn{2}{|c|}{$\begin{array}{c}\text { The number of fertile aged women } \\
\text { with uterine leiomyoma }\end{array}$} \\
\hline $\begin{array}{c}\text { Somatoform dysfunction of autonomic } \\
\text { nervous system }\end{array}$ & 35 & $\%$ (range) \\
\hline $\begin{array}{c}\text { Gastrointestinal tract: } \\
\text { gastritis } \\
\text { cholecystitis }\end{array}$ & 12 & $66.0(53.3-78.8)$ \\
\hline $\begin{array}{c}\text { Diseases of the upper respiratory tract: } \\
\text { chronic tonsillitis }\end{array}$ & 14 & $22.6(11.4-33.9)$ \\
\hline $\begin{array}{c}\text { Diseases of the urinary tract: } \\
\text { urolithiasis } \\
\text { cystitis }\end{array}$ & 10 & $26.4(14.5-38.3)$ \\
\hline * $p=0.0188$ & 3 & $18.9(8.3-29.4)$ \\
\hline
\end{tabular}

Unfortunately, a significant number of fertile aged women with uterine leiomyoma had bad habits (Tab. 16), the most frequently occurring was smoking (43.4\%) and excessive alcohol consumption (9.4\%).

\section{TABLE 16. BAD HABITS IN FERTILE AGED WOMEN WITH UTERINE FIBROIDS}

\begin{tabular}{|c|c|c|}
\hline \multirow{2}{*}{ Bad habits } & \multicolumn{2}{|c|}{$\begin{array}{c}\text { The number of fertile aged women } \\
\text { with uterine leiomyoma }\end{array}$} \\
\hline Smoking & $n$ & $\%$ (range) \\
\hline Excessive alcohol consumption & 23 & $43.4(30.1-56.7)$ \\
\hline $\begin{array}{c}\text { Excessive use of psychotropic drugs and } \\
\text { medicines }\end{array}$ & 5 & $9.4(1.6-17.3)$ \\
\hline
\end{tabular}

It should be noted that women with uterine leiomyoma actively used methods of contraception (Tab. 17).

\section{TABLE 17. CONTRACEPTIVE CHOICES IN FERTILE AGED WOMEN WITH UTERINE FIBROIDS}

\begin{tabular}{|c|c|c|}
\hline $\begin{array}{c}\text { Methods of } \\
\text { contraception }\end{array}$ & $\begin{array}{c}\text { The number of fertile aged women } \\
\text { with uterine leiomyoma }\end{array}$ \\
\hline Barrier & $n^{*}$ & $\%$ (range) \\
\hline Intrauterine device & 14 & $26.4(14.5-38.3)$ \\
\hline Oral & 12 & $22.6(11.4-33.9)$ \\
\hline Not used & 17 & $32.1(19.5-44.6)$ \\
\hline${ }^{*} p=0.00151$ & 10 & $18.9(8.3-29.4)$ \\
\hline
\end{tabular}


Most often women with uterine leiomyoma were using oral hormonal contraceptives (32.1\%), barrier methods (26.4\%) and intrauterine device $(22.6 \%), 18.9 \%$ of women were not using contraceptives.

\section{CONCLUSIONS}

1. The problem of uterine leiomyoma is important for fertile aged women residents of Dniprovskyi district and for Kyiv overall, with the incidence of uterine leiomyoma in fertile aged women was $5.1 \%$ per 1000 women, which is slightly higher than the average according to the official statistics (4.4\% per 1000 women).

2. Gynecological diseases and conditions that can be considered as risk factors of uterine leiomyoma revealed in

\section{REFERENCES/תITEPATYPA}

\section{1. Жилка, Н.Я, Іркіна, Т.К., Тешенко, В.}

Стан репродуктивного здоров'я в Україні: Медико-демографічний огляд. — К.: М03

України, НАН України, Інститут економіки. — 2001. — 68 с.

Zhylka, N.Y., Irkina, T.K., Teshenko, V.

Reproductive health in Ukraine: Medical-demographic survey. Kyiv. MOH of Ukraine, NAMS of

Ukraine, Institute of Economics (2001): 68 p.

2. Подольський, В.В.

Репродуктивне здоров'я жінок - важлива проблема сучасності / В.В. Подольський //

Здоровье женщины. — 2003. — №1 (13). - С. 100-104.

Podolskyi, V.V.

"Reproductive health is an important health problem of our time."Women's Health, 1(13) (2003): 100-104.

3. Камінський, В.В.

Збереження репродуктивного здоров'я жінки - основа формування здорової нації /

В.В. Камінський, Л.Б. Маркін та ін. // Здоров'я України. — 2008. — №9. — C 58-59.

Kaminskyi, V.V., Markin, L.B., et al.

"Reproductive health of women of a healthy nation - the foundation of a healthy nation." Health of Ukraine, 9(2008): 58-59.

4. Руководство по эндокринной гинекологии /

Под ред. Е.М. Вихляевой. — М.: Мед. информ. — 1997.

Endocrine Gynecology Guidelines // Ed. by E.M. Vikhlyaeva.

Moscow. Med. Inform (1997).

5. Стрижаков, А.Н., Давыдов, А.И., Пашков, В.М., Лебедев, В.А.

Доброкачественные заболевания матки. — М.: ГЭОТАР. — 2011. — 288 с.

Strizhakov, A.N., Davidov, A.I., Pashkov, V.M., Lebedev, V.A.

Benign diseases of the uterus. Moscow. GEOTAR (2011): $288 \mathrm{p}$. high rates of examined fertile aged women. Among them, chronic pelvic inflammatory diseases had $64.2 \%$ women; polycystic ovary syndrome had $32.0 \%$; cervical erosion $22.6 \%$; artificial abortions had $71.7 \%$ women with uterine leiomyoma.

3. In fertile aged women residents of the industrial region of Ukraine with uterine leiomyoma among social factors noteworthy is young age (30 to 40 years), by marital status women had well-being families $(62.9 \%)$, mostly they had higher education $(52.8 \%)$ and by social status were workers (20.8\%) and employees (49.0\%).

4. In women with uterine leiomyoma frequently observed clinical manifestations violations of autonomic homeostasis such as somatoform dysfunction of the autonomic nervous system (66.0\%).

\section{6. Тихомиров, А.Л.}

Патогенетическое обоснование профилактики миомы матки / А.Л. Тихомиров,

А.А. Леденкова, А.Е. Батаева // Вопросы гинекологии, акушерства и перинатологии. 2011. — №1 (10). - C. 75-78.

Tikhomirov, A.L., Ledenkova, A.A., Bataeva, A.E." "Pathogenetic substantiation of prevention of uterine fibroids." Questions of Gynecology, Obstetrics and Perinatology, 1(10) (2011): 75-78. 7. Atlas of health in Europe WHO I EURO (2003): 50-51, 170-179.

8. Hill, C.A., Harris, R.C., Kim, H.J., et al.

"Influence of beta-alanine supplementation on skeletal muscle carnosine concentrations and high intensity cycling capacity." Amino Acids, 32(2) (2007): 225-233.

9. Захарьян, Е.A.

Нейроциркуляторная дистония - патология соединительного матрикса / Е.А. Захарьян, В.Ф. Кубышкин, В.А. Ионов // Крымский журнал экспериментальной и клинической медицины. 一 2011. —№ 2 (2), Т. 1. —C. 116.

Zakharian, E.A., Kubyshkin, V.A., Ionov, V.A.

"Neurocirculatory dystonia as a pathology of coupling matrix." Crimean Journal of Experimental and Clinical Medicine, 2(2), Vol. 2 (2011): 116.

10. Акушерство та гінекологія:У 4 т.: національний підручник /

За ред. акад. НАМН України, проф. В.М. Запорожана // Т. 4. Оперативна гінекологія. -

К.: «Медицина». - 2013. - 1070 c.

National tutorial «Obstetrics and Gynecology» /

Ed. by academic of the NAMS of Ukraine, professor V.M. Zaporozhan. Kyiv. Medicine. Vol. 4 (2013): $1070 \mathrm{p}$.

\section{CLINICAL AND EPIDEMIOLOGICAL CHARACTERISTICS OF FERTILE AGED WOMEN WITH UTERINE LEIOMYOMA, RESIDENTS OF INDUSTRIAL REGION OF UKRAINE}

V.M. Zaporozhan, MD, Professor, Vice President of the Academy of Medical Sciences of Ukraine, Rector of Odesa National Medical University, Head of the Obstetrics and Gynaecology Department № 1 VI.V. Podolskyi, candidate of med. sciences, head of the research group, senior researcher, head of the Department of Health Problems of Fertile Aged Women, State Institution "Institute of Pediatrics, Obstetrics and Gynecology of the National Academy of Medical Science of Ukraine"

Results of study provided in population of fertile aged women are showed in the article, clinical and epidemiological characteristics of women with uterine leiomyoma, which are living in the industrial region of Ukraine. Revealed frequency and structure of appearance of uterine leiomyoma and factors, that could lead to uterine leiomyoma.

Thus, the incidence of uterine leiomyoma in fertile aged women at Dniprovskyi district of Kyiv was $5.1 \%$ per 1000 women, which is slightly higher than the average according to the official statistics (4.4\% per 1000 women).

Keywords: fertile aged women, uterine leiomyoma, risk factors.

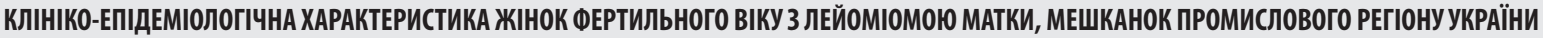

В.М. Запорожан, д. мед. н., професор, віце-президент НАМН України, ректор Одеського НМУ, завідувач кафедрою акушерства та гінекології № 1

Вл.В. Подольський, к. мед. Н., керівник наукової групи, старший науковий співробітник, завідувач відділенням проблем здоров'я жінок фертильного віку ІПАГ НАмН України

В результаті проведених досліджень у популяції жінок фертильного віку надана клініко-епідеміологічна характеристика жінок із лейоміомою матки, які мешкають у промисловому регіоні України. 3'ясовані частота і структура лейоміоми матки та факторів, що можуть призводити до цього захворювання.

Так, захворюваність на лейоміому матки в жінок фертильного віку Дніпровського району м. Києва склала 5,1\% на 1000 жінок, що дещо перевищує середній статистичний офіційний показник (4,4\% на 1000 жінок).

Ключові слова: жінки фертильного віку, лейоміома матки, фактори ризику.

\section{КЛИНИКО-ЭПИДЕМИОЛОГИЧЕСКАЯ ХАРАКТЕРИСТИКА ЖЕНЩИН ФЕРТИЛЬНОГО ВОЗРАСТА С ЛЕЙОМИОМОЙ МАТКИ, ЖИТЕЛЬНИЦ ПРОМЫШЛЕННОГО РЕГИОНА УКРАИНЫ}

В.Н. Запорожан, д. мед. н., профессор, вице-президент НАМН Украины, ректор Одесского НМУ, заведующий кафедрой акушерства и гинекологии № 1

Вл.В. Подольский, к. мед. Н., руководитель научной группы, старший научный сотрудник, заведующий отделением проблем здоровья женщин фертильного возраста ИПАГ НАМН Украины

В результате проведенных исследований в популяции женщин фертильного возраста представлена клинико-эпидемиологическая характеристика женщин с лейомиомой матки, живущих в промышленном регионе Украины. Выяснены частота и структура лейомиомы матки, а также факторов, которые могут приводить к этому заболеванию.

Так, заболеваемость лейомиомой матки у женщин фертильного возраста Днепровского района г. Киева составила 5,1\% на 1000 женщин, что несколько превышает средний статистический официальный показатель (4,4\% на 1000 женщин).

Ключевые слова: женщины фертильного возраста, лейомиома матки, факторы риска. 